\title{
GENDER DIFFERENCES IN THE ADOPTION OF MOBILE BANKING: REVIEW OF USING TAM ON BANKING CUSTOMERS
}

\author{
Agung Sugiarto \\ Universitas Katolik Soegijapranata
}

\begin{abstract}
Mobile banking as a manifestation of the use of technology in the banking sector, has a very massive deployment level. This study focuses on the use of mobile banking technology as one of the products of information technology in the banking field. Gender differences of mobile banking users empirically shown to be affected by several factors that can be identified through modeling framework technology acceptance model (TAM), including: perceived usefulness and perceived ease of use.
\end{abstract}

Keywords: TAM; perceived usefulness; perceived ease of use

\section{INTRODUCTION}

Technological developments have different effects according to the context in which it is located and applied. But in general, the features of a technology is a crucial matter of a technology that includes: attributes, characteristics or functions of the technology concerned. Features are used as parameters or criteria when a user adopts the hardware or software (Griffith, 1999).

In the context of business world, the evolution of information technology has a massive impact. Business transactions can be carried out and processed electronically, without physical documentation (paperless). In addition, the information can be presented in real time, which affects on the quality of decision-making which can be improved (Rezaee, 2001). Information technology can be interpreted as a key to support and improve the practice of management, in order to win the competition that is becoming increasingly. Companies are required to be able to adapt to the needs of increasingly diverse society and expanding market segment, both demographically and geographically. Information technology is also one of the factors in determining whether a product marketed will be able to compete in local and international markets.

This study focuses on the use of mobile banking technology as one of the products of information technology in the banking sector. Result of the research conducted by Gefen and Straub (1997) concludes that there is no difference in perception between men and women in using electronic mail (e-mail) technology. Venkantesh and Morris (2000) states that there are gender differences that affect the adoption of new technologies that form the desire to use new technologies. While Cameron and Powell (2006) states that there are gender differences in the use of information technology among IT professionals. 
Research conducted by Kim et al (2009) examines on the technology acceptance model (TAM) whether it affects on the performance of internal auditor. The result indicates that there is a significant effect between perceived usefullness, perceived ease of use, on the system usage, there is a significant effect between perceived ease of use to perceives usefullness. Organizational factors significantly affect on the perceived ease of use. Individual factors significantly affect on the perceived usefullness. While social factors do not significantly affect the perceived usefullness and perceived ease of use.

TAM theory proposed by Davis (1986) explains that TAM consists of the system usage, intention to use, behavior to use, perceived usefulness, perceived ease of use, and external variables. System usage is a key indicator of technology acceptance (Davis et al, 1989; Thompson et al, 1991, Adams et al, 1992) and measured by the frequency and time (Davis et al, 1989). Trust or internal main confidence for the behavior of reception including perceived usefulness and perceived ease of use. Perceived usefulness and perceived ease of use has a positive relationship with technology acceptance (Davis et al, 1989). First introduced by Davis (1986), Technology Acceptance Model (TAM) is a model used to analyze the factors that affect the acceptance of computer technology utilization. TAM is the development of Theory of Reasoned Action (TRA). The goal of TAM is to explain and predict user's acceptance about information systems.

Here is a schema of TAM theoretical framework:

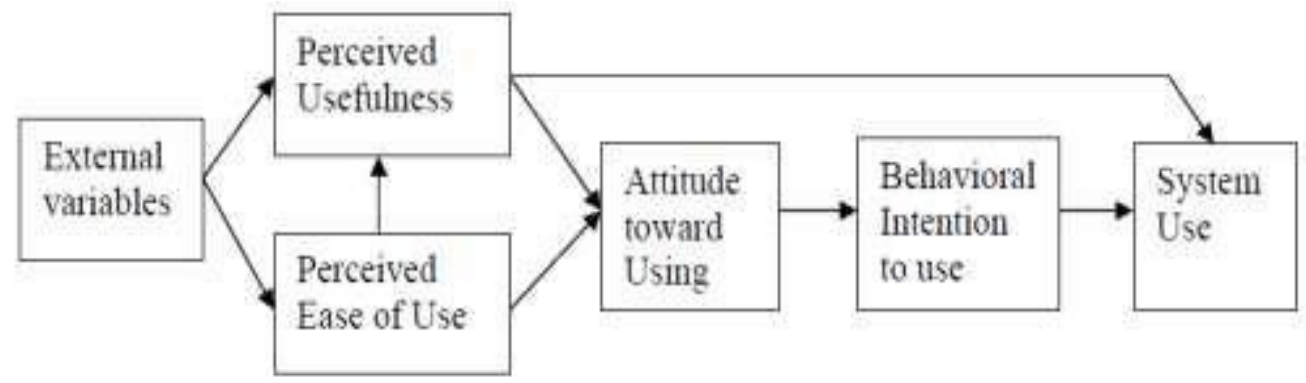

Source: Davis et.al. (1986)

According to Davis et al. (1989), the perception of usefulness benefits (perceived usefulness) is "a level where a person believes that using the system can improve his/her performance in the work". Perceived ease of use is "a level where a person believes that using the system do not need to make effort. Attitude toward using or usage behavior in the context of TAM theory is the attitude towards the use of the system in the form of acceptance or rejection as a result when someone uses a technology in his/her work. While behavioral intention to use is the behavioral tendency to use a technology.

Perceived usefulness or perception of technology usefulness is a level where a person believes that using a particular system will enhance or improve his/her performance (Davis et al, 1989). From the definition, it can be concluded that perceived usefulness is a belief about a decision-making process, or in other words it can be said when a person trusts in an information system that is believed to be useful, then he/she will use it (Jogiyanto, 2007). This concept describes the benefits of the system for the users associated with the level of productivity, task and effectiveness performance, as well as the importance of a task and overall usefulness (Davis, 1989). 
Perceived ease of use / perception of ease in the use of technology is a degree to which a person believes that the use of system / particular technology will be easily done, free from problems (Davis et al, 1989). While attitude toward using according to Aakers and Myers (1997), is an like or dislike attitude on the use of a product. This attitude can be used to predict the behavior of one's intention to use a product or not to use it. Attitudes toward using technology is also defined as an evaluation from the user regarding his interest in using the technology.

Two other variables adopted in this study is the intention to use and gender. Davis (1989) defines the intention to use as a behavioral tendency to continue using a technology. The use level of a technology on a person can be predicted from user's attention attitude to the technology, for example, the desire to add support equipment (peripheral), motivation to continue using, as well as a desire to motivate other users. Suseno's research results (2009) also states that the interest of behaviour using the technology (behavioral intention to use) is the impulse or the interests in a person to perform certain behaviors.

The last variable is gender. Showalter (1989) argues that the meaning of gender is more than just the distinction between men and women seen on the socio-cultural construction. He presses it as an analytic concept that is able to be used to explain something. So that gender is a concept which is often used to identify the differences between men and women, which can be viewed from non-biological angle namely the social, cultural and psychological aspects. This study aims to examine and obtain empirical evidence about the influence of gender differences on TAM, as well as the influence between perceived usefullness, perceived ease of use towards the attitude toward using and intention to use on the adoption of mobile banking technology.

There is 7 hypothesis proposed in this study, namely:

$\mathrm{H1}$ : There are differences in perceived usefulness of mobile banking technology between men and women. $\mathrm{H} 2$ : There are differences in perceived ease of use on mobile banking technology between men and women. H3: There are differences on attitude toward using mobile banking technology between men and women. $\mathrm{H} 4$ : There are differences on intention to use mobile banking technology between men and women.

H5: There is influence of perceived usefullness on attitude toward using mobile banking.

H6: There is influence of perceived ease of use on attitude toward using Mobile banking.

H7: There is influence of attitude toward using on intention to use Mobile banking.

\section{METHODS}

In this study, it was used a sample of customers of Bank Rakyat Indonesia (BRI) and Bank Central Asia (BCA) in the city of Semarang, with the criteria: having and using mobile banking facility and using it at least 3 times in the last 3 months. It was expected with this criterion, the respondents have had experience (use experience) in using the technology. Measurement instruments in this study was using TAM questionnaire developed by Davis (1986). From the results of the questionnaire which distributed in this study to the respondents, it was obtained 106 questionnaires that could be processed further to examine the hypothesis proposed above. 
Furthermore, before conducting hypothesis testing, first, the validity and reliability tests were conducted on the questionnaire results obtained from the respondents. From the test results, the questionnaire used in this study was valid and reliabel, so that it was able to be examined further in hypothesis testing. In this study, it was used t-test difference test to test to examine hypothesis 1 until hypothesis 4 , in order to determine whether there were gender differences in the use of mobile banking. Criteria for acceptance of the hypothesis was if the value of sig. $\mathrm{t}<0.05$ then the hypothesis was accepted, otherwise if the value of sig. $t>0.05$ then the hypothesis was rejected. While, to examine hypothesis 5 until hypothesis 7 , it was used a regression model to determine the effect of variable $\mathrm{X}$ to $\mathrm{Y}$ with the criteria if the value of sig. $t<0.05$ then the hypothesis was accepted, and vice versa if the value of sig. $t>0.05$ then the hypothesis was rejected.

\section{RESULTS AND DISCUSSION}

Result of hypothesis 1 testing showed that there was a difference in perceived usefullness of M-Banking technology between men and women. This result could be seen from the testing result with the significance probability level of $t$ was $0.000<0.05$. The result indicated that the first hypothesis which stated that there was a difference in perceived usefullness of M-Banking technology between men and women was acceptable. The level of perceived usefullness differences between men and women that were different in technology adoption, it was supposed as a result of differences in mobile banking facilities utilized. Types of transactions that conducted by male respondents on average were more complex than women, as the impact of men role which was more dominant in the business world.

For variable PEOU, it was obtained the F count value of Levene test as big as 1,298 with probability of $0.257>0.05$, then it could be said that the samples had the same variance. Therefore, the analysis of $t$-test difference test used an assumption of equal variance assumed. Result of $t$ significance probability testing was $0.000<0.05$. It showed that the second hypothesis which stated that there were differences in perceived ease of use of M-Banking technology between men and women was acceptable. It meant that there were differences in perceived ease of use of M-Banking technology between men and women. This situation showed that gender differences affected the perceived ease in the adoption of mobile banking technology. The banking sector needed to think about different treatment on their customers (according to gender) so that the penetration rate of mobile banking facilities has increased.

The third hypothesis testing results with variable of attitude toward using obtained the F count value of Levene test as big as 3.437 ; with probability of $0.067>0.05$ so that it could be said that the samples had the same variance. Therefore, the analysis of t-test difference test used an assumption of equal variance assumed. The test results of probability with a significance level of $t$ was $0.000<0.05$. It indicated that the third hypothesis which stated that there were differences on the attitude toward using M-Banking technology between men and women was accepted. It means that there were differences on the attitude toward using M-Banking technology between men and women, as a result of the differences in perceived 
ease of use in the technology adoption between two different gender, as described in the two previous hypotheses.

Later, the fourth hypothesis testing, it was obtained the result of $t$ significance probability level as big as $0,007<0.05$. The result indicated that the fourth hypothesis which stated there were differences on the intention to use M-Banking technology between men and women was accepted. It meant that there were differences on the intention to use mobile banking technology between men and women. The result could be interpreted as an accumulation of $1^{\text {st }}$ to $3^{\text {th }}$ hypothesis which stated there were gender differences in the adoption of TAM, both in terms of perceived usefulness, perceived ease of use and attitude toward using.

\section{Testing Table for $\mathrm{H} 1-\mathrm{H} 4$ (Gender)}

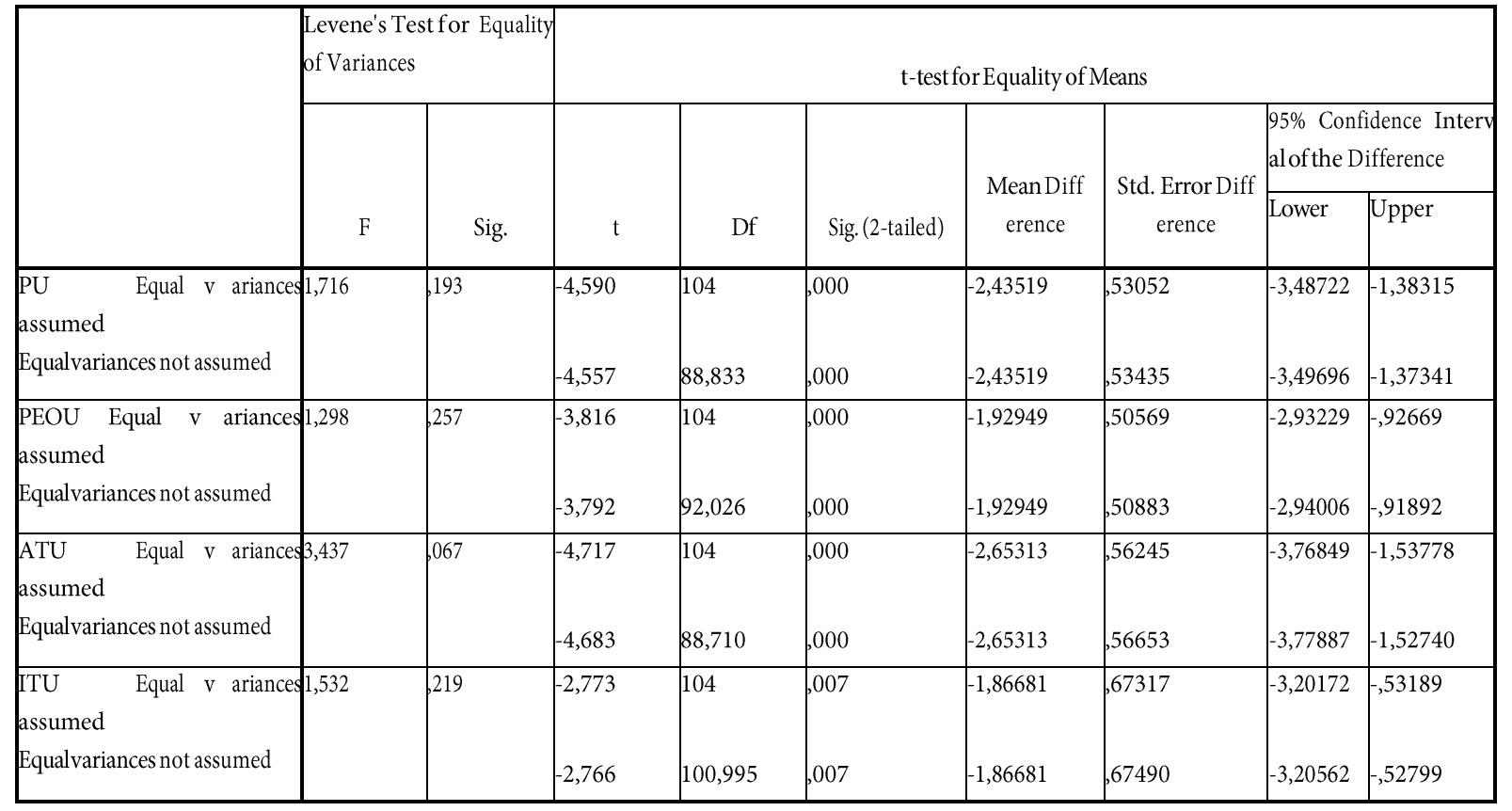

Source: Primary Data Processed (2015)

The next testing was on hypotheses 5 until 7. Before conducting testing on these hypotheses, first it was conducted classical assumption testing. The result of classical assumption testing showed that the samples used were able to meet the assumption of normality, did not occur heterocedasticity, and did not occur multicollinearity between variables in the model. The results of hypothesis 5 and hypothesis 6 testing is presented as follows:

Table of Hypothesis 5 - Hypothesis 6 Regression Analysis Testing Result Coefficients $^{\mathrm{a}}$

\begin{tabular}{|c|c|c|c|c|c|c|}
\hline \multirow{3}{*}{\multicolumn{2}{|c|}{ Model }} & \multicolumn{2}{|c|}{ Unstandardized Coefficients } & \multirow{3}{*}{$\begin{array}{l}\text { Standardized } \\
\text { Coefficients } \\
\text { Beta } \\
\end{array}$} & & \multirow{3}{*}{ Sig. } \\
\hline & & & & & & \\
\hline & & $B$ & Std. Error & & & \\
\hline & (Constant) &,- 074 & 1,151 & &,- 065 & 949 \\
\hline & PEOU & .233 & 091 & ,203 & 2,556 & 012 \\
\hline & $\mathrm{PU}$ & ,759 &, 085 & & 8,952 &, 000 \\
\hline
\end{tabular}


a. Dependent Variable: ATU

From the result of regression testing output above, the variable of perceived usefullness had value of sig.t as big as $0.000<0.05$. Thus, the fifth hypothesis was accepted, which meant there was influence of perceived usefullness on the attitude toward using mobile banking. As for the significance of perceived ease of use variable, it was obtained result of sig.t value amounted to $0.012<0.05$ which meant the sixth hypothesis was accepted. It meant that there was influence of perceived ease of use on attitude toward using mobile banking. Perception of usefulness and ease in the adoption of mobile banking technology empirically proven effected on attitude (intention) to adopt mobile banking technology.

\section{Table of Hypothesis 7 Regression Analysis Testing Result} Coefficients $^{\mathrm{a}}$

\begin{tabular}{|c|c|c|c|c|c|c|}
\hline & \multirow{2}{*}{ Model } & \multicolumn{2}{|c|}{ Unstandardized Coeff icients } & \multirow{2}{*}{$\begin{array}{l}\text { Standardized } \\
\text { Coefficients } \\
\text { Beta }\end{array}$} & \multirow{2}{*}{$\mathrm{t}$} & \multirow{2}{*}{ Sig. } \\
\hline & & B & Std. Error & & & \\
\hline \multirow[t]{2}{*}{1} & (Constant) & 1,339 & 1,472 & & 909 & ,365 \\
\hline & ATU & 882 & ,069 & 783 & 12,849 &, 000 \\
\hline
\end{tabular}

a. Dependent Variable: ITU

Based on the result of regression analysis, it was obtained a significance level of attitude toward using variable was sig.t of $0000<0: 05$ so that the seventh hypothesis was accepted. It meant that there was the influence of attitude toward using on the intention to use mobile banking. In line with the results of hypothesis 5 and 6 testing, then with the perception of the usefulness and ease in the adoption of mobile banking technology that encouraged an attitude to adopt these technologies, it could be ascertained that these attitudes would surely be realized into action to use it.

\section{CONCLUSIONS}

Based on the explanation and testing results in this study, it is obvious that gender factor has a significant influence in the adoption of mobile banking facility. Some suggestions can be submitted to the banking sector related to the results of this study include: The bank may consider customers gender in determining the development strategy of mobile banking facility, because it proved significantly affect the use of the facility. For example, the bank can use promotional / advertising strategy based on gender, different facilities according to customers gender. Accuracy in product development certainly enhance the success of products, which leads to the company's profitability.

In a similar study in the future, it can be considered to use other variables or use moderating variables and other variables, such as security or security of the facility. This study cannot be separated from weakness, that is using samples at BCA (private bank) and BRI (state banks) but more respondents which are from BCA, so it has impact on the perception toward the use of mobile banking facility which is dominated by the private bank respondents. In addition, the number of relatively little respondents is also another weakness in this study, which affects the generalization of the results that can be done. 


\section{REFERENCES}

Adams, D.A., Nelson, R.R. and Todd, P.A. 1992. "Perceived usefulness, ease of use, and usage of information technology: a replication". MIS Quarterly. June, pp. 227-47.

Ajzen, I. 1975. "The Theory of Planned Behavior," Organizational Behavior and Human Decision Processes (50:2), pp. 179-211.

Berninghausen and Kerstan, 1992. Forging New Path. Feminist Social.

Methodological and Rural Women in Java.

Bierstaker, James L, Burnaby, Priscilla dan Thibodeau. 2001. The Impact of Information Technology on The Audit Process: an Assessment of The State of The Art and Implications for The Future. Managerial Auditing Journal. Vol.16, No.3 : 159 - 164.

Davis, F. D. 1986. "Perceived Usefulness, Perceived Ease of Use, and User Acceptance of Information Technology," MIS Quarterly (13:3), pp. 319- 339.

Elaine, Showalter. 1989. Feminist criticism: essays on women, literature and theory. New York: Pantheon Book.

Fishbein, M., and Ajzen, I. 1975. Belief, Attitude, Intention and Behavior: An Introduction to Theory and Research, Addison-Wesley, Reading, MA.

Gefen, D., and Straub, D.W. 1997. "Gender differences in the perception and use of e-mail: An Extension to the Technology Acceptance Model,” MIS Quarterly (21:4), pp. 389-400.

Ghozali, I. 2004. Analisis Multivariate dengan Program SPSS. Semarang: Undip.

Griffith TL. 1999. Technology features as triggers for sensemaking. Acad ManagRev; 24(3):472-88.

Harrison dan Datta, 2007. Akuntansi. Jakarta: Erlangga.

Jogiyanto, 2007. Sistem Informasi Keperilakuan, Andi Offset Yogyakarta

Kim, Hyo-Jeong, Michael Mannino, Robert J. Nieschwietz. 2009. Information technology acceptance in the internal audit profession: Impact of technology features and complexity. International Journal of Accounting Information Systems 10 (2009) 214-228

Rezaee, Zabihollah. 2001. Continuous Auditing :The Audit of The Future.Managerial Auditing Journal Vol.16 No. 3 : $150-158$

Sugiyono, 2009. Metode Penelitian Bisnis. Bandung: CV Alfabeta.

Thompson, R. L., Higgins, C. A., and Howell, J. M. 1991. "Personal Computing: Toward a Conceptual Model of Utilization," MIS Quarterly (15:1), pp. 125-143.

Venkatesh, V., Morris, M. G.2000. Why Don't Men Ever Stop to Ask For Directions? Gender, Social Influence and Their Role in Technology Acceptance and Usage Behavior. Management Information System Quarterly Vol. 24 No. 1, Maret 2000. 